\title{
PROGESTERONE LEVELS FOLLOWING TREATMENT OF SEASONALLY ANOESTROUS EWES WITH SYNTHETIC LH-RELEASING HORMONE
}

\author{
W. HARESIGN, J. P. FOSTER, N. B. HAYNES, D. B. GRIGHTON \\ AND G. E. LAMMING \\ Department of Physiology and Environmental Studies, University of Nottingham, \\ School of Agriculture, Sutton Bonington, Loughborough, Leicestershire LE12 5RD
}

(Received 9th September 1974)

\begin{abstract}
Summary. Plasma progesterone determinations were carried out on blood samples collected daily from Clun Forest ewes during the normal oestrous cycle and also after administration of LH-releasing hormone (LH-RH) during seasonal anoestrus.

Levels of plasma progesterone at oestrus ranged from 0.1 to $0.5 \mathrm{ng} / \mathrm{ml}$ and luteal phase levels from 3 to $6 \mathrm{ng} / \mathrm{ml}$. Levels found during seasonal anoestrus were within the range of those observed at oestrus. Following treatment with LH-RH, there was an increase in the plasma LH level in all cases and ovulation occurred in twenty-three out of twenty-seven treated ewes. In the animals which ovulated, the plasma progesterone concentration either remained basal (eighteen animals) or rose to a lower level $(<2 \mathrm{ng} / \mathrm{ml})$ than that found during the luteal phase of the cycle.
\end{abstract}

\section{INTRODUCTION}

The determination for LH-releasing hormone (LH-RH) of a decapeptide structure (Matsuo, Baba, Nair, Arimura \& Schally, 1971) and synthesis of this material (Geiger, König, Wissmann, Geisen \& Enzmann, 1971) has provided a valuable tool for the study of reproductive function in the sheep.

The ability of this synthetic decapeptide to induce release of LH and FSH from the ovine pituitary both in vivo and in vitro is well established (Arimura, Debeljuk, Matsuo \& Schally, 1972; Crighton \& Foster, 1972; Foster \& Crighton 1973; Jonas \& co-authors, 1973). Apparent ovulation was induced in most animals when LH-RH was given as a single intravenous injection to seasonally anoestrous ewes (Crighton, Foster, Haresign, Haynes \& Lamming, 1973; Foster \& Crighton, 1973).

Reports on subsequent luteal function following the induction of ovulation with LH-RH are lacking. The purpose of this communication is to present data on plasma progesterone levels following the treatment of seasonally anoestrous Glun Forest ewes with a single intravenous injection of either $150 \mu \mathrm{g}$ or $300 \mu \mathrm{g}$ LH-RH.

A brief preliminary report of this work has already appeared (Crighton et al., 1973). 
Animals

\section{MATERIALS AND METHODS}

Clun Forest ewes, 4 to 5 years old, were used throughout the experiment. All ewes were housed indoors with a vasectomized ram under natural lighting conditions. All cycling ewes were shown to have had at least two normal oestrous cycles before they were used. All seasonally anoestrous ewes had given birth to lambs during the preceding December and January, and were checked for cyclic activity with a colour-marked vasectomized ram for at least 17 days before treatment.

\section{Collection of blood samples}

Blood samples for plasma progesterone determinations were collected daily by jugular venepuncture for 2 days before and 20 days after administration of the decapeptide. Samples for LH assay were collected through an indwelling jugular cannula, inserted $24 \mathrm{hr}$ before treatment, every $10 \mathrm{~min}$ for $1 \mathrm{hr}$ before and every $5 \mathrm{~min}$ for $3 \mathrm{hr}$ after administration of LH-RH.

The blood was centrifuged immediately after collection at $4^{\circ} \mathrm{C}$ and $1600 \mathrm{~g}$ for $15 \mathrm{~min}$ and the plasma removed and stored at $-20^{\circ} \mathrm{C}$ until assayed.

\section{Experimental design}

Experiment 1 . Ten seasonally anoestrous ewes, five in each group, were given a single intravenous injection of either $150 \mu \mathrm{g}$ or $300 \mu \mathrm{g} \mathrm{LH}-\mathrm{RH}$ during the period May to June. Four ewes received saline alone or synthetic tripeptide (thyrotrophin-releasing hormone, TSH-RH) to serve a scontrols. Crighton \& Foster (1972) showed that this tripeptide did not cause elevation of plasma LH levels. All ewes were subjected to laparotomy 3 to 4 days after treatment for examination of the ovaries.

To provide an estimate of levels of progesterone during the luteal phase for this breed of sheep under similar conditions of surgery to those imposed on the experimental ewes, another group of four ewes was given either saline or TSH-RH on Day 12 of the oestrous cycle. The animals were subjected to laparotomy on Day 14 or 15 of the cycle and again 3 or 4 days after the onset of the next oestrus.

Experiment 2. During May and June 1973 and 1974 a further seventeen seasonally anoestrous ewes were given $150 \mu \mathrm{g} \mathrm{LH}-\mathrm{RH}$ by intravenous injection and treated subsequently as described for Exp. 1.

\section{Assay of progesterone}

Chemicals and equipment. Petroleum ether (b.p. 30 to $60^{\circ} \mathrm{C}$ ) was Nanograde (Mallenckrodt Ghemical Works, St Louis) and was not purified further. The $\left[1,2-{ }^{3} \mathrm{H}\right]$ progesterone (sp. act. $53 \mathrm{Ci} / \mathrm{mmol}$ ) was obtained from the Radiochemical Centre, Amersham. Dextran-charcoal solution was made by mixing equal volumes of a $0.4 \%$ charcoal (Norite A: Sigma Chemical Co.) suspension and a $0.2 \%$ dextran (Grade $\mathrm{C}$, British Drug Houses Ltd) solution, both in $0.1 \mathrm{M}$-phosphate buffer ( $\mathrm{pH} 7.1$ ), and containing $0.1 \%$ by weight of gelatin and sodium azide. Liquid scintillation counting was carried out using a Tracerlab coru/matic 200 counter with a scintillator composed of $4.0 \mathrm{~g}$ of 
2,5-diphenyloxazole and $0.5 \mathrm{~g}$ of p-bis-2-(5-phenyloxozolyl)-benzene in 1.0 litre toluene.

Assay procedure. Plasma progesterone was assayed using an antiserum raised in goats. Appropriate duplicate volumes of plasma $(0.25 \mathrm{ml}$ for luteal levels, $0.5 \mathrm{ml}$ in other cases) were transferred to test-tubes and extracted twice with 4 vols light petroleum ether. This procedure involved thorough mixing of the plasma and light petroleum on a Vortex mixer, centrifugation at $1500 \mathrm{~g}$ for 5 min and freezing at $-20^{\circ} \mathrm{C}$ for $30 \mathrm{~min}$. The organic phase was then decanted into a second series of tubes and evaporated to dryness for assay. Ten aliquots from random plasma samples were used for estimating the loss of steroid during the extraction stage in each assay. In these cases, $0 \cdot 1 \mathrm{ml}\left[1,2-{ }^{3} \mathrm{H}\right]$ progesterone in benzene $(2000 \mathrm{ct} / \mathrm{min})$ were added to each tube and dried down before the addition of the plasma sample. After mixing on a Vortex mixer and incubation at $45^{\circ} \mathrm{C}$ for $15 \mathrm{~min}$, the samples for recovery estimates were extracted as above and the total extract assessed for radioactivity. A series of standards $(0.05,0 \cdot 1$, $0 \cdot 2,0 \cdot 4,1 \cdot 0,2 \cdot 0$ and $4 \cdot 0 \mathrm{ng}$ progesterone) were prepared in duplicate. Antiserum at a $1: 3000$ dilution in phosphate buffer $(0 \cdot 1 \mathrm{ml})$ was added to both plasma samples and standards and the mixture incubated at room temperature for 30 min. After this time $\left[1,2-{ }^{3} \mathrm{H}\right]$ progesterone $(0 \cdot 1 \mathrm{ml})$ in phosphate buffer $(10,000$ $\mathrm{ct} / \mathrm{min}$ ) was added to all tubes. The contents of the tubes were mixed and incubated at $4^{\circ} \mathrm{C}$ for at least $8 \mathrm{hr}$. Two water blanks consisting of $0.5 \mathrm{ml}$ glassdistilled deionized water were processed with the plasma samples in each assay. After incubation, the separation of antibody-bound and free steroid was performed at $4^{\circ} \mathrm{C}$. Dextran-charcoal suspension $(1.0 \mathrm{ml})$ was added to each assay tube, the contents were agitated on a Vortex mixer, allowed to stand at $4^{\circ} \mathrm{C}$ for $10 \mathrm{~min}$ and centrifuged at $1500 \mathrm{~g}$ for a further $10 \mathrm{~min}$. The supernatant solution was decanted into a scintillation vial containing $1.0 \mathrm{ml}$ ethyl alcohol. Scintillation fluid $(10 \mathrm{ml})$ was then added to each vial which was shaken and the radioactivity was counted after allowing time for separation of the two phases.

Reliability criteria for progesterone assay. Specificity studies were carried out on the antiserum and gave results essentially similar to those reported by Furr (1973).

Twenty water blanks measured during the assays contained $26 \pm 3 \mathrm{pg}$ progesterone equiv./tube. The average recovery of progesterone (seventeen assays) was $62 \cdot 7 \pm 3 \cdot 2 \%$. Within assays, the coefficient of variation for recoveries was never greater than $\pm 2.5 \%$. Sensitivity of the assay, defined as twice the S.D. of blank values was $20 \mathrm{pg} /$ tube. Accuracy was assessed by adding known quantities of progesterone to $0.5 \mathrm{ml}$ aliquots of plasma from castrated male sheep and assaying the extracts. The mean concentrations for four samples in each determination were: $0.1 \mathrm{ng}$ added, $0.11 \pm 0.01 \mathrm{ng}$ measured; $0.20 \mathrm{ng}$ added, $0.19 \pm 0.01 \mathrm{ng}$ measured; $0.40 \mathrm{ng}$ added, $0.40 \pm 0.02 \mathrm{ng}$ measured; $1.00 \mathrm{ng}$ added, $0.96 \pm 0.03 \mathrm{ng}$ measured; $2.00 \mathrm{ng}$ added, $2.02 \pm 0.03 \mathrm{ng}$ measured. The coefficient of variation of duplicate pairs, calculated by the method of Snedecor (1952) and incorporating both intra- and inter-assay variation was $3.30 \%$ for values of 0.8 to $4.0 \mathrm{ng} / \mathrm{ml}$ (twenty samples) and $9.62 \%$ for values $<0.8 \mathrm{ng} / \mathrm{ml}$ (thirty samples). Duplicate $0.5-\mathrm{ml}$ aliquots of plasma from a seasonally anoestrous ewe and $0 \cdot 25-\mathrm{ml}$ aliquots from a ewe in the last third of 
gestation were measured in each assay. These gave values of $0 \cdot 11 \pm 0 \cdot 01 \mathrm{ng} / \mathrm{ml}$ and $10.03 \pm 0.66 \mathrm{ng} / \mathrm{ml}$ respectively (fourteen samples).

\section{Assay of $\mathrm{LH}$}

A double-antibody radioimmunoassay (Foster \& Crighton, 1975) was used to estimate the LH concentrations of plasma samples. The antiserum used was raised in rabbits by intradermal injection of a solution of a partly purified LH preparation in an emulsion with Freund's complete adjuvant at 3-week intervals. The LH preparation used had an activity of half that of NIH-LH-S1 in the ovarian ascorbic acid depletion (OAAD) bioassay. A modified version of the method described by Greenwood, Hunter \& Glover (1963) was used for the radioiodination of a highly purified $\mathrm{LH}$ preparation with ${ }^{125} \mathrm{I}$.

The LH activity of this preparation was 1.8 times that of NIH-LH-S1 in the OAAD bioassay.

Assay method. A solution was prepared consisting of normal rabbit serum (NRS) at 1:400 dilution in assay diluent and antiserum at a dilution known to give approximately $50 \%$ binding of the labelled hormone $(1: 20,000) ; 0.2 \mathrm{ml}$ of this solution was added to reaction tubes containing $0.5 \mathrm{ml}$ of solutions of known concentration of standard LH (NIH-LH-S17, National Institutes of Health, U.S.A.) or known dilution $(1: 10$ or $1: 20)$ of test material. The tubes were incubated at $4^{\circ} \mathrm{C}$ for $24 \mathrm{hr}$ and $0.2 \mathrm{ml}$ of a solution of labelled LH, diluted to give $10,000 \mathrm{ct} / \mathrm{min} / 0.2 \mathrm{ml}$, was added. The tubes were counted to determine total counts and were incubated for $18 \mathrm{hr}$ at $4^{\circ} \mathrm{C}$ before $0.1 \mathrm{ml}$ of a $1: 30$ dilution of anti-rabbit $\gamma$-globulin (MR66, Burroughs Wellcome \& Co.) was added. The tubes were incubated for a further $6 \mathrm{hr}$ at $4^{\circ} \mathrm{C}$, and after centrifugation, the supernatants were removed and the precipitates counted.

The LH concentrations of plasma samples were calculated by interpolating the $\%$ binding obtained on the standard curve. A quantity of $0.5 \mathrm{ng}$ NIH-LH$\mathrm{S} 17 / \mathrm{ml}$ generally gave $10 \%$ inhibition of binding. Negligible cross-reactions were observed with ovine FSH, growth hormone and prolactin. A purified preparation of thyroid-stimulating hormone (TSH) was not available. There were no differences, however, between the levels of LH detected by the assay in plasma samples obtained before and after treatment of ewes with $300 \mu \mathrm{g}$ TSH-RH, suggesting that the cross-reaction with TSH was low.

When a standard curve was prepared using NIH-LH-S17 made up in plasma from hypophysectomized sheep $(1: 10, \mathrm{v} / \mathrm{v})$ instead of assay diluent, there was a slight $(<2 \%)$ decrease in $\%$ binding at each concentration; an indication that interference from the plasma itself was negligible.

When various preparations containing ovine $\mathrm{LH}$ were evaluated by both the OAAD bioassay and radioimmunoassay, the Mean Index of Discrimination ( $\frac{\text { biological assay }}{\text { radioimmunological assay }}$ ) was 1.29 (range from 1.00 to 1.97 ).

The limit of sensitivity of the assay was generally $1 \mathrm{ng}$ NIH-LH-S17 equiv./ml (Foster, 1974).

\section{Experiment 1}

\section{RESULTS}

Ovarian activity. At laparotomy, four of the five ewes in each of the groups 
treated with either $150 \mu \mathrm{g}$ or $300 \mu \mathrm{g}$ LH-RH during seasonal anoestrus had apparently normal ovulation points (see Table 1). The other two treated sheep showed considerable follicular development but had no ovulation points. None of the four control ewes that received tripeptide or saline alone showed signs of ovarian activity. The uteri of the treated ewes were still typical of seasonally anoestrous ewes.

Table 1. The effect of treatment with LH-RH on LH and progesterone levels and ovulation in seasonally anoestrous ewes

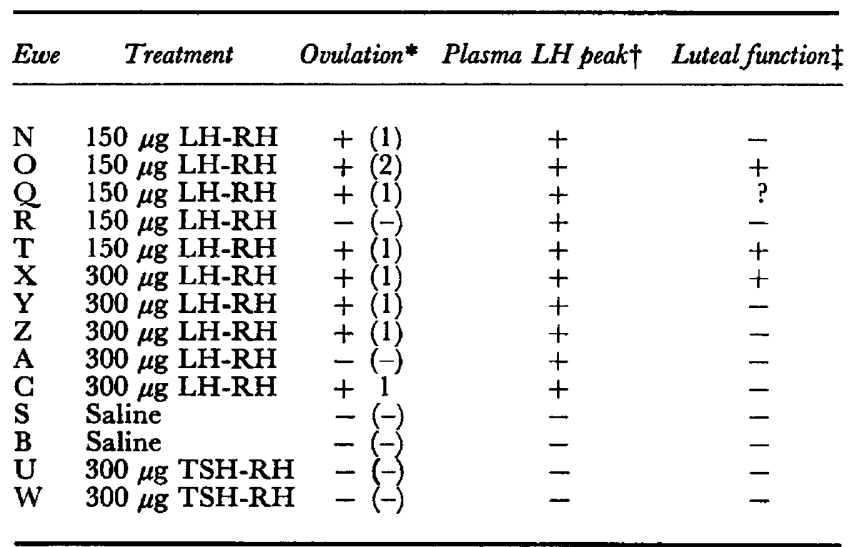

\footnotetext{
* The number of ovulation points are indicated in parentheses.

$\dagger+$ indicates elevation; - indicates no rise.

$\$$ indicates elevation above basal levels of plasma progesterone; - indicates the plasma progesterone levels remained basal. For sheep $Q$, see text and Text-fig. 4.
}

The four ewes receiving saline or TSH-RH on Day 12 of the oestrous cycle (1st day of oestrus = Day 0 ) had not ovulated by the time of laparotomy on Day 14 or 15, but all these ewes came into oestrus on Days 16 to 18 and had ovulated normally at laparotomy 3 to 4 days later.

Oestrus was not detected in any sheep treated with decapeptide even though most ewes ovulated.

Levels of $L H$. Treatment with LH-RH resulted in increased plasma LH levels in all ewes (see Text-figs 3, 4 and 5; Table 1). The plasma LH concentration rose within 20 to $40 \mathrm{~min}$ and the peak level was reached 90 to $120 \mathrm{~min}$ after injection in all ewes. There was no increase in the plasma LH concentration following injection of saline alone or $300 \mu \mathrm{g}$ TSH-RH (Text-fig. 1; Table 1).

Progesterone levels. Progesterone levels in the four control ewes given saline or TSH-RH during seasonal anoestrus did not rise significantly above pre-injection values (see Text-fig. 1). A typical example of progesterone levels in the four ewes given saline or TSH-RH on Day 12 of the cycle is shown in Text-fig. 2. Mid-cycle levels ranged from 3.6 to $5.4 \mathrm{ng} / \mathrm{ml}$ in these ewes.

Individual plasma progesterone levels for the four ewes showing some evidence of luteal function after administration of LH-RH during seasonal anoestrus are shown in Text-figs 3 and 4. At laparotomy, all of these four ewes were observed to have apparently normal ovulation points on the surface of their 


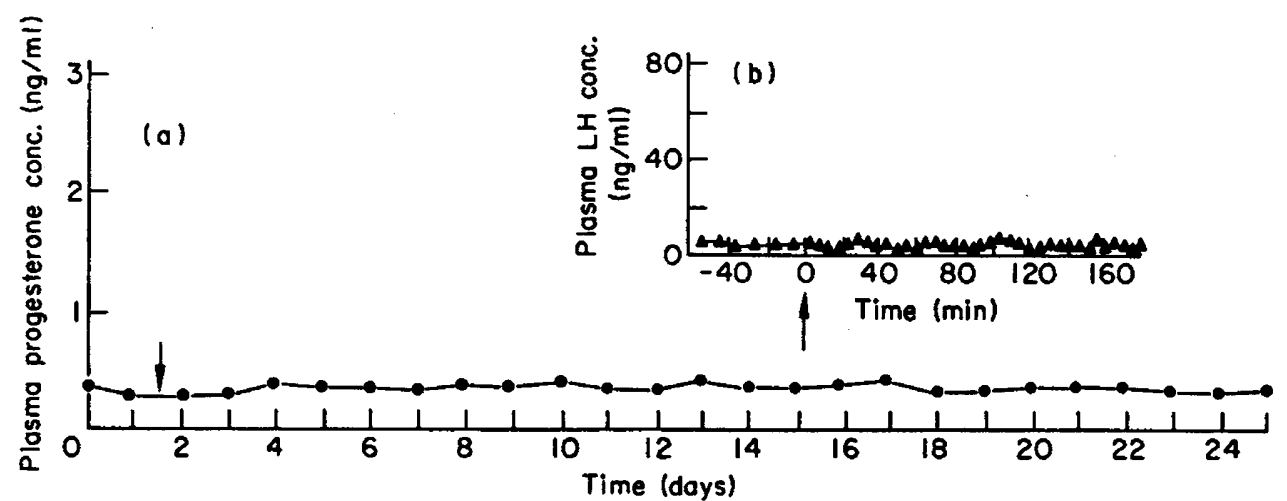

Texr-FIG. 1. Peripheral plasma progesterone (a) and LH (b) concentrations in an anoestrous ewe given saline (arrows).

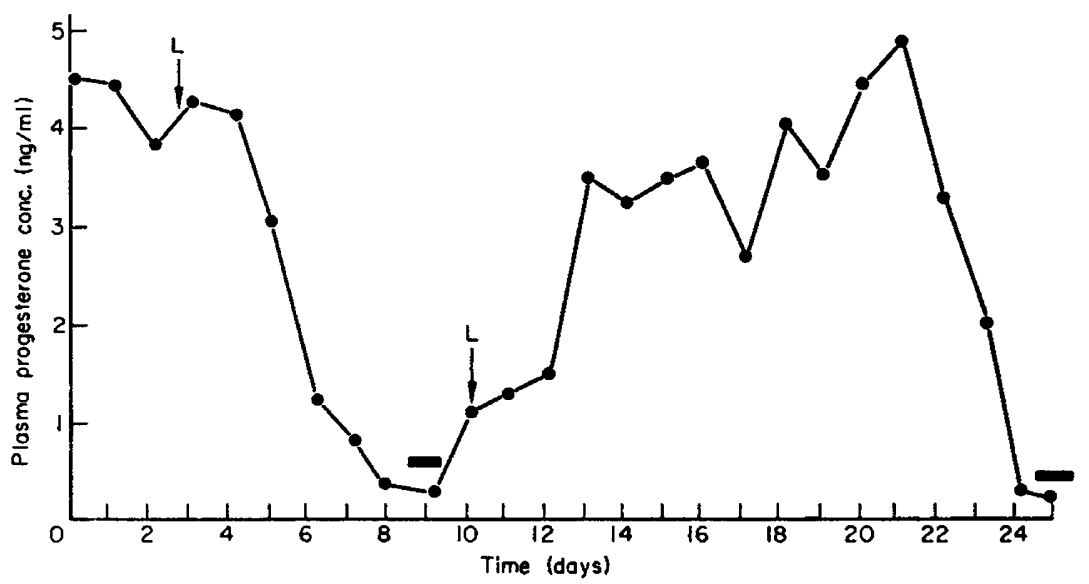

Text-rig. 2. Peripheral plasma progesterone levels in a ewe during the oestrous cycle.

The horizontal bars indicate the time of oestrus; $L$ denotes the time of laparotomy.

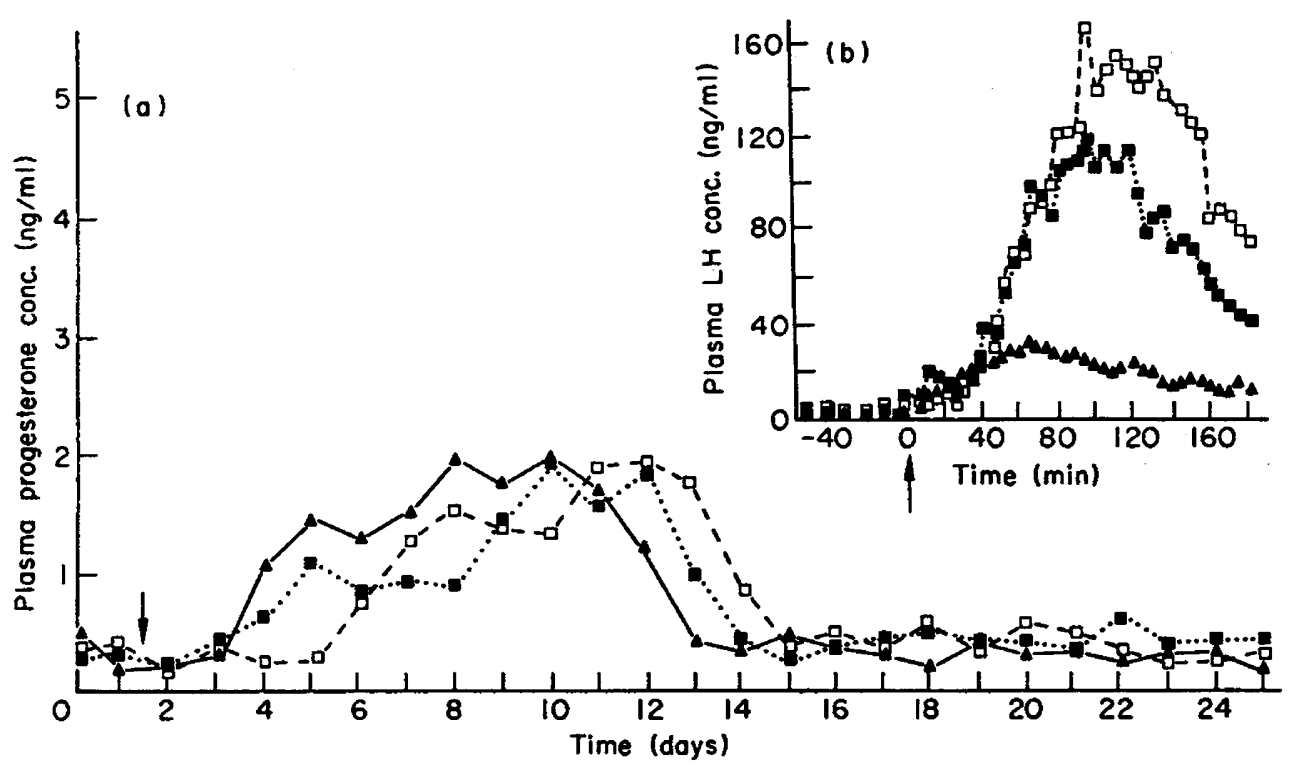

TExT-FIG. 3. Peripheral plasma progesterone (a) and LH (b) levelsin ewes $\mathbf{O}(\mathbf{A})$; $\mathbf{T}$ (2) (回) $12: 22: 17 \mathrm{PM}$ and $X(\square)$. The arrows indicate the time of administration of LH-RH. 


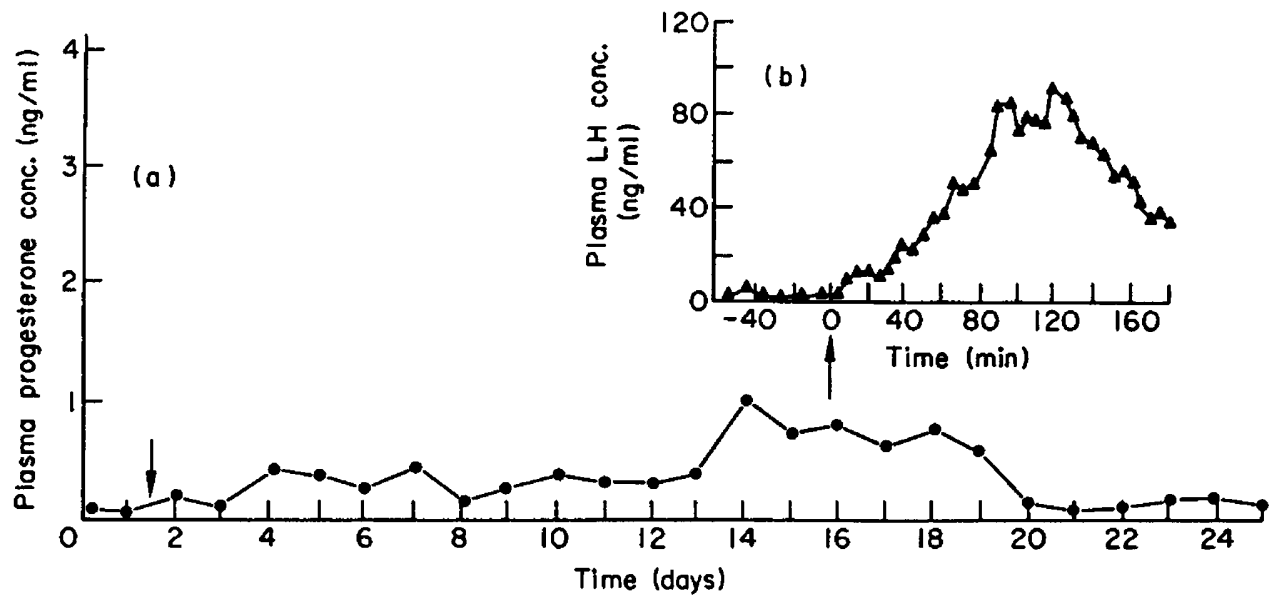

TexT-FIG. 4. Peripheral plasma progesterone (a) and LH (b) in ewe $Q$. The arrows indicate the time of administration of $150 \mu \mathrm{g}$ LH-RH.

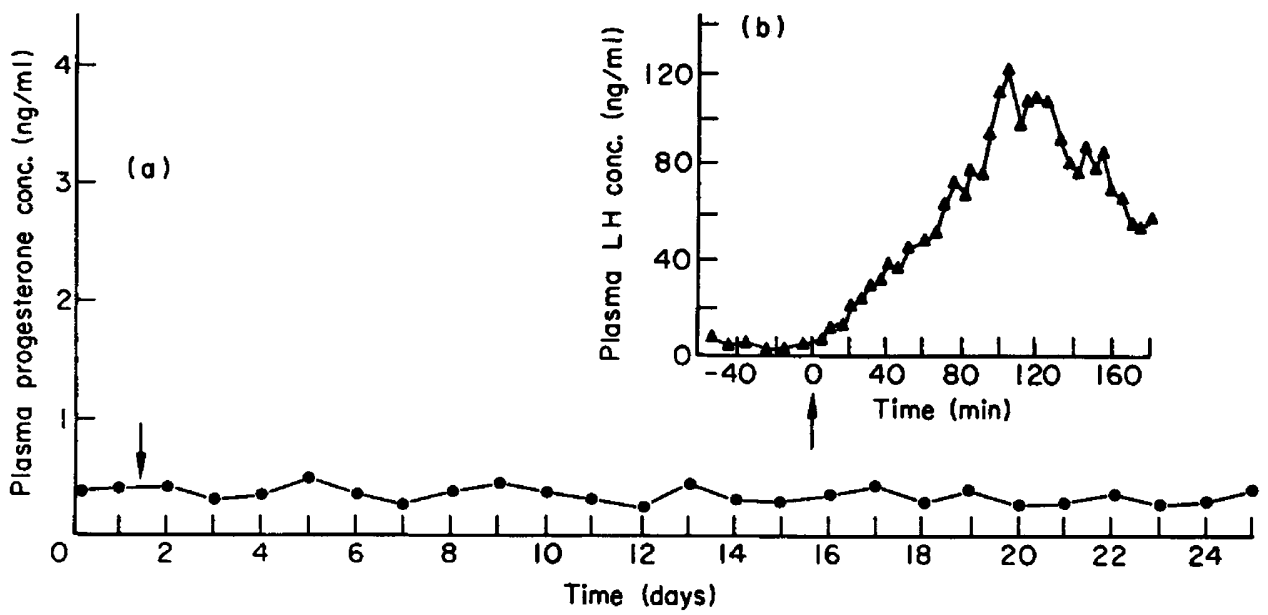

TexT-FIG. 5. Peripheral plasma progesterone (a) and LH (b) levels in ewe C. The arrows indicate the time of administration of $300 \mu \mathrm{g} \mathrm{LH}-\mathrm{RH}$.

ovaries. In three of the ewes (Ewes $\mathrm{O}, \mathrm{T}$ and X; Text-fig. 3), the levels began to rise about 2 days after treatment and remained elevated for 10 to 12 days. The maximum levels attained in these three ewes did not exceed $2.0 \mathrm{ng} / \mathrm{ml}$. The fourth ewe (Ewe Q; Text-fig. 4) was atypical in that a small rise was observed in plasma progesterone between Days 12 to 18 after injection, although the maximum level was only $1.0 \mathrm{ng} / \mathrm{ml}$.

Plasma progesterone levels did not rise significantly (see Text-fig. 5) in the remaining six experimental ewes, four of which had apparently normal ovulation points.

\section{Experiment 2}

All seventeen ewes showed an increased plasma LH level and sixteen had 
apparently normal ovulation points at laparotomy, averaging 1.25/ewe. The remaining animal had extensive follicular development. An elevation of subsequent plasma progesterone above the basal level was only detected in two animals that had ovulation points. The profiles resembled those of Ewes $\mathrm{X}, \mathrm{T}$ and $\mathrm{O}$ (Text-fig. 3 ) and the maximum level attained was $1.4 \mathrm{ng}$ progesterone $/ \mathrm{ml}$.

\section{DISCUSSION}

The general pattern of $\mathrm{LH}$ release in Clun Forest ewes in response to single intravenous injections of $150 \mu \mathrm{g}$ or $300 \mu \mathrm{g}$ LH-RH has been reported previously (Foster \& Crighton, 1973; Crighton, Scott \& Foster, 1974), and is similar to that recorded by Arimura et al. (1972) after intra-arterial and intramuscular injection of $250 \mu \mathrm{g} \mathrm{LH}-\mathrm{RH}$, and by Reeves, Arimura, Schally, Kragt, Beck \& Casey (1972) following each of two intramuscular injections of $200 \mu \mathrm{g}$ LH-RH given $4 \mathrm{hr}$ apart.

In the present study, considerable variation in LH response was observed with both doses of LH-RH used. The height and duration of the LH peaks induced by administration of LH-RH are known to be much less than those of the natural peak before ovulation (Grighton et al., 1974). Individual variation in the height of $\mathrm{LH}$ peaks was too great to allow correlation between the occurrence of apparent ovulation and the height of the LH peak (Foster \& Grighton, 1973). Ovulation points seen at laparotomy appeared macroscopically normal and did not differ significantly in number between control and treated animals. It was considered inadvisable to attempt recovery of ova from these animals since subsequent experiments required that they be disturbed as little as possible during ovarian examination. Evidence that the ovulation points do represent true ovulations is provided by the work of K. Seeger (personal communication) and W. Haresign (unpublished data) who have recovered ova from the reproductive tracts of anoestrous ewes treated with LH-RH.

Macroscopic examination of the ovaries indicated greater follicular development in all the ewes treated with LH-RH than in the controls. This is in accord with the results of Crighton \& Foster (1972), Crighton (1972) and Jonas et al. (1973) which show that LH-RH will induce release of FSH in vitro and in vivo.

The lack of behavioural oestrus in treated ewes which ovulated was expected, since priming with progesterone is required before oestrus accompanies ovulation in the ewe (Robinson, 1954). The uteri of ewes treated with LH-RH, however, were typical of the anoestrous state. This observation suggests that even though follicular development occurred, this was not accompanied by secretion of a level of oestrogen sufficient to stimulate the uterus to the same degree as that seen at a natural oestrus. The reason for this is not clear.

The pattern of progesterone production obtained from daily samples throughout the oestrous cycle in the four control cyclic ewes was the same as that recorded by other workers (Stabenfeldt, Holt \& Ewing, 1969; Thorburn, Bassett \& Smith, 1969; Smith \& Robinson, 1969; McNatty, Revfeim \& Young, 1973), but the mean levels tended to be higher. There is no obvious explanation for this but similar levels were recorded for Clun Forest ewes using a competitive 
protein-binding technique for plasma progesterone (W. Haresign and N. B. Haynes, unpublished data).

In all but one of the treated ewes that did show evidence of progesterone production, the pattern was similar to that observed in control cyclic ewes but the maximum levels obtained $(2 \mathrm{ng} / \mathrm{ml})$ were lower than those reported for control animals ( 3 to $6 \mathrm{ng} / \mathrm{ml}$ ) in this study. This may not, however, reflect abnormal progesterone production since the results could be explained by the fact that anoestrous ewes have a somewhat higher metabolic clearance rate for progesterone than do cyclic animals (Bedford, Harrison \& Heap, 1972). In Ewe $Q$ (Text-fig. 4) the progesterone response was definitely abnormal. The levels remained basal for the first 10 to 11 days after treatment, then showed a rise to levels of $1 \mathrm{ng} / \mathrm{ml}$ for a period of 5 days. The reason for this atypical response is not clear. Notwithstanding the fact that a proportion of the ewes induced to ovulate show some evidence of progesterone production after LH-RH treatment, the majority do not. It is unlikely that the basal levels of peripheral plasma progesterone recorded throughout in these animals can be explained by changes in the metabolic clearance rate and suggest either a lack of luteal tissue formation, or the formation of luteal tissue which does not produce progesterone. The reasons are not obvious. Laparotomy cannot be considered responsible for the lack of progesterone production, since control cyclic ewes all showed normal peripheral plasma progesterone levels when laparotomy was performed for the second time 3 to 4 days after oestrus, an equivalent time after ovulation to that used for ewes induced to ovulate with LH-RH during seasonal anoestrus. Furthermore, McNatty et al. (1973) found that laparotomy increased peripheral plasma progesterone levels. Piper \& Foote (1968) demonstrated that when ewes were induced to ovulate on Day 4 of the cycle by injection of oestradiol- $17 \beta$, the CL was only maintained when oestradiol-17 $\beta$ injections were continued daily, even though the CL formed at the previous ovulation were maintained naturally. This suggests that a stimulus for functional maintenance of the CL in the normal situation is released at about the time of ovulation. Denamur (1968) showed that hypophysectomy soon after ovulation resulted in the formation of a histologically normal CL up to Day 12 of the cycle, but progesterone secretion was abnormal. It has also been suggested that the luteotrophin in sheep may be a combination of prolactin and LH (Denamur, Martinet \& Short, 1973). It is possible therefore that the normal luteotrophic stimulus is lacking in most anoestrous ewes induced to ovulate with LH-RH and this could explain the lack of normal luteal function in this study.

The present experiments do not allow a distinction between two possibilities; that the low concentration of plasma progesterone is a result of retarded growth of GL, or development of CL which do not produce progesterone. Further work is in progress to clarify this situation.

Whilst injection of $\mathrm{LH}-\mathrm{RH}$ will cause $\mathrm{LH}$ release and ovulation in anoestrous sheep, subsequent plasma progesterone concentrations usually remain basal. This would seem to preclude the use of LH-RH as a single injection without other therapy for the induction of reproductive activity in the anoestrous ewe. 


\section{AGKNOWLEDGMENTS}

The authors wish to thank Mr J. Best of Hoechst Pharmaceuticals for supplies of the synthetic decapeptide and the National Institutes of Health, U.S.A., for standard LH. The antiserum raised in goats was kindly donated by $\mathrm{Dr}$ B. J. A. Furr. This work was conducted while one of us (J.P.F.) was in receipt of a Science Research Council postgraduate studentship, and another (W.H.) was supported by a postgraduate studentship from the Ministry of Agriculture, Fisheries and Food.

\section{REFERENCES}

Armura, A., Debeljuk, L., Matsuo, H. \& Schally, A. V. (1972) Release of luteinizing hormone by synthetic LH-releasing hormone in the ewe and ram. Proc. Soc. exp. Biol. Med. 139, 851-854.

Bedford, G. A., Harrison, F. A. \& Heap, R. B. (1972) The metabolic clearance rate and production rate of progesterone and the conversion of progesterone to 20a-hydroxypregn-4-en-3-one in the sheep. F. Endocr. 55, 105-118.

Crigriron, D. B. (1972) The effect of a synthetic decapeptide on the release of luteinizing hormone and follicle-stimulating hormone from ovine pituitary tissue in vitro. F. Physiol., Lond. 226, 68p-69p.

CRIGHTON, D. B. \& FosteR, J. P. (1972) The effects of a synthetic preparation of gonadotrophin releasing factor on gonadotrophin release from the ovine pituitary in vitro and in vivo. F. Endocr. 55, xxiiixxiv.

Crighton, D. B., Foster, J. P., Haresign, W., Haynes, N. B. \& Lamming, G. E. (1973) The effects of a synthetic preparation of gonadotrophin releasing factor on pituitary and ovarian function in anoestrous ewes. F. Physiol., Lond. 231, 98p-99p.

Crrghton, D. B., ScotT, S. A. \& Foster, J. P. (1974) An attempt to simulate, by injection of luteinizing hormone releasing hormone in the anoestrous sheep, the pattern of release observed at oestrus and the effects of this on luteinizing hormone release. 7. Endocr. 61, lxiii-lxiv.

Denamur, R. (1968) Formation and maintenance of the corpus luteum in domestic animals. F. Anim. Sci., Suppl. 27, 163-180.

Denamur, R., Martinet, J. \& Short, R. V. (1973) Pituitary control of the ovine corpus luteum. $\mathcal{F}$. Reprod. Fert. 32, 207-220.

Foster, J. P. (1974) Luteinizing hormone release and ovulation in the ewe. Ph.D. thesis, University of Nottingham.

Foster, J. P. \& CRighton, D. B. (1973) Preliminary observations on the administration of a synthetic preparation of gonadotrophin releasing factor to cyclic and anoestrous ewes. F. Endocr. 57, xxv.

Foster, J. P. \& Crighton, D. B. (1975) Luteinizing hormone (LH) release after single injections of a synthetic LH-releasing hormone (LH-RH) at three different reproductive stages and comparison with the natural LH release at oestrus. Theriogenology, (in press).

FurR, B. J. A. (1973) Radioimmunoassay of progesterone in the peripheral plasma of the domestic fowl in various physiological states and in follicular venous plasma. Acta endocr., Copenh. 72, 89-100.

Geiger, R., König, W., Wissmann, H., Geisen, K. \& Enzmann, F. (1971) Synthesis and characterisation of a decapeptide having LH-RH/FSH-RH activity. Biochem. biophys. Res. Commun. 45, 767-773.

Greenwood, F. C., Hunter, W. M. \& Glover, J. S. (1963) The preparation of ${ }^{131}$ I-labelled human growth hormone of high specific reactivity. Biochem. 7. 89, 114-123.

Jonas, H. A., Salamonsen, L. A., Burger, H. G., Chamley, W. A., Cumming, I. A., Findlay, J. K. \& GodrNG, J. R. (1973) Release of FSH after administration of gonadotrophin-releasing hormone or estradiol to the anoestrous ewe. Endocrinology, 92, 862-865.

McNatty, K. P., Revfeim, K. J. A. \& Young, A. (1973) Peripheral plasma progesterone concentrations in sheep during the oestrous cycle. $\mathcal{F}$. Endocr. 58, 219-225.

Matsuo, J., Baba, Y., Nair, R. M. G., Arimura, A. \& Schally, A. V. (1971) Structure of the porcine LH- and FSH-releasing hormone. Y. The proposed amino acid sequence. Biochem. biophys. Res. Commun. 43, 1334-1339.

PtPeR, E. L. \& Foote, W. C. (1968) Ovulation and corpus luteum maintenance in ewes treated with $17 \beta$-oestradiol. F. Reprod. Fert. 16, 253-259.

Reeves, J. J., Arimura, A., Schally, A. V., Kragt, C. L., Beck, T. W. \& Casey, J. M. (1972) Effects of synthetic lyteinizing hormone-releasing hormone/follicle stimulating hormone-releasing hormone (LH-RH/FSH-RH) on serum LH, serum FSH and ovulation in anestrous ewes. 7. Anim. Sci. 35, 84-89. 
Robinson, T. J. (1954) Necessity for progesterone with estrogen for the induction of recurrent estrus in the ovariectomised ewe. Endocrinology, 55, 403-408.

Smith, J. F. \& Robinson, T. J. (1969) Luteal function in the Merino ewe and the effect of exogenous progestagen. F. Endocr. 44, 79-89.

SNEDECOR, G. W. (1952) Query 92. Biometrics, 8, 85-86.

Stabenfeldt, G. H., Holt, J. A. \& Ewing, L. L. (1969) Peripheral plasma progesterone levels during the ovine estrous cycle. Endocrinology, 85, 11-15.

Thorburn, G. D., Bassetr, J. M. \& Smrth, I. D. (1969) Progesterone concentration in the peripheral of plasma sheep during the oestrous cycle. $\mathcal{F}$. Endocr. 45, 459-469. 